УДК 621.331 .922

\title{
ANALYSIS OF EFFECTIVENESS OF PROCESS OPERATIONAL AND TECHNOLOGICAL RELIABILITY OF AGRICULTURAL MASHINES
}

\author{
R. F. Ovchar \\ National University of Life and Environmental Sciences of Ukraine, Ukraine. \\ Speciality of article: 133 - industry engineering. \\ Corresponding author: rfovchar@gmail.com
}

Article history: Received-August 2020, Accepted-October 2020.

Bibl. 23, fig. 0, tabl. 1 .

Abstract. The analysis suggests that to solve the contradiction between the need of ensuring the required level of serviceability of combine harvesters and capabilities of existing system and repair management of the technical state of combine harvesters at the present stage, there is a need to improve the subsystem recovery combine harvesters subject to the requirements of readiness to perform tasks on purpose and financial capacity for its maintenance.

Analysis of scientific literature showed that today the unsolved problem of search and introduction of effective methods and repair combine harvesters are: development of mathematical models of the process and repair, which would allow comparative assessment of technical and economic efficiency of different modes, and repair objects combine harvesters, alternative strategies for their repair, with the aim of improving the quality of control of technical condition of the vessel in conditions of limited funding.

Consideration of the process of technical maintenance of combine harvesters as a set of stages and repair objects combine harvesters allows to identify possible directions of improving the system restore. The analysis allowed to determine four basic options for its organization and to make a qualitative assessment of the benefits and disadvantages of each of these options.

Reduced operating costs in the operation of combine harvesters, along with other measures of organizational and technical nature require greater automation of control of technical condition. Automation of technical state control of combine harvesters developed in the following areas: embedded systems control, on-board automated control systems, specialized control systems and universal control systems dismantled equipment. A large share of false failures in equipment, violation of industrial relations in the repair network on-board equipment, the shortage of maintenance fund requires implementation and operation.

Most fully able to examine the efficiency of the process of operation of complex technical systems using analytical models.

Existing approaches to the assessment of the recovery system can be classified also according to the used indicators of effectiveness: the number of constructive variables of units that are replaced (restored) for a predetermined period of operation of the control object, repair cost of the constituent elements of the functional system for a specific period at different depths of the control and completeness of the recovery, the downtime of the test object within a certain period, for comprehensive reliability, such as coefficient of readiness, coefficient of technical use.

Key words: analyze, effectiveness, process, operation, technology, reliability, combine.

\section{Introduction}

As is known, the choice of indicators to assess the effectiveness of the process, which is investigated, is an important part of the analysis, the quality of which depend the results of the analysis and the objectivity of rational choice (optimal for the modern period) solutions.

\section{Formulation of problem}

In this regard, in the modern period in literature, which is devoted to techno-economic analysis of the efficiency of operation of complex technical systems (CTS), has developed three main approaches [1-12]:

- evaluation of the effectiveness of one composite index (scalar),

- based on a number of indicators (vector),

- evaluation metrics used in common, the most important indicators.

\section{Analysis of recent research results}

Under the effectiveness of any technical system understand the degree of completeness of implementation of the tasks set before her, and the magnitude of costs associated with its implementation under certain conditions and time interval [13-20]. Efficiency is characterized by the intensity of its manifestation, which is called the index of effectiveness [21]. Thus, the efficiency index $\mathrm{W}$ is a measure of the degree of 
conformity of real result $\mathrm{Y}$ the result is what you want (goal) SW. In turn, based on the goal of the recovery subsystem on-Board equipment of the vessel [22], the goal of the process and $\mathrm{R}$, and hence the process of technical operation (PTO) SK associated with the costs of various resources: material $\mathrm{C}$, Tr employment, financial $\mathrm{F}$, time $\mathrm{T}$, and the resource. Therefore, when evaluating the effectiveness of the recovery process objects combine harvesters it is necessary to consider, in addition to the target score $\mathrm{g}$, and the costs of different resources $(\mathrm{C}, \mathrm{Tr}$, $\mathrm{F}, \mathrm{T}$ ) occurring when executing operations. It follows that the efficiency indicators of operational modes of the objects combine harvesters must have a technical and economic nature [23].

\section{Purpose of research}

In paper carried out the analytical and generalization analysis and evaluation of performance indicators of process operational and technological reliability of combine harvesters.

\section{Results of research}

Thus, the results $\mathrm{Y}$ the recovery process, combine harvesters, what is studied, is an R-dimensional vector of characteristics result the operating rules including the appropriate groups component $R=r_{1}+r_{2}+r_{3}+\ldots$ :

$$
Y^{\langle R\rangle}=\left(g^{\left\langle r_{1}\right\rangle}, C^{\left\langle r_{2}\right\rangle}, T_{r}^{\left\langle r_{3}\right\rangle}, F^{\left\langle r_{5}\right\rangle}, \ldots\right)
$$

That is, the result required, should also be represented by a target vector to lodging,

$$
Y_{B}^{\langle R\rangle}=\left(g_{8}^{\langle r 1\rangle}, C_{8}^{\langle r 2\rangle}, \operatorname{Tr}_{8}^{\left\langle r_{3}\right\rangle}, F_{8}^{\left\langle r_{5}\right\rangle}, \ldots\right)
$$

what sets the boundaries of permissible values of the corresponding indicators $Y^{(R)}$ of real result of the operation process that is studied.

To describe the correspondence between $Y$ and $Y_{6}$ use some numerical function $\rho$ on the set of the results of the recovery process that is considered, and that is a function matching:

$$
\rho=\rho\left(Y(u), Y_{\mathrm{B}}\right), \quad u \in U
$$

where: $U$ the many options for organizing the recovery process, which represent the system of rules of control of technical condition of the objects combine harvesters for maintenance or repair, which directly determine the scope (volume) the type and frequency of recovery operations.

The magnitude of the correspondence between elements of the same name the component $Y$ and $Y_{B}$ :

$$
\left\{\begin{array}{l}
\rho_{1}^{g}\left(g_{1}, g_{1_{\text {B. }}}\right) \\
\rho_{2}^{g}\left(g_{2}, g_{2 \text { b. }}\right) \\
\ldots \ldots \ldots . . . \ldots . . . . . \\
\rho_{r_{1}}^{g}\left(g_{r_{1}}, g_{r_{1} \text { B. }}\right)
\end{array}\right\},
$$

$$
\begin{aligned}
& \left\{\begin{array}{l}
\rho_{1}^{C}\left(C_{1}, C_{1 b}\right) \\
\rho_{2}^{C}\left(C_{2}, C_{2 b}\right) \\
\ldots \ldots \ldots \ldots \ldots . . . . . . . . \\
\rho_{r_{2}}^{C}\left(C_{r_{2}}, C_{r_{2} b}\right)
\end{array}\right\},
\end{aligned}
$$

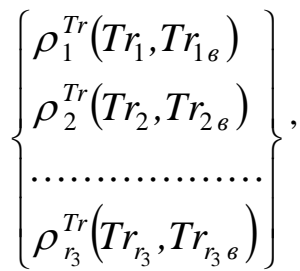

define the set of partial performance indicators $W_{g}^{\left\langle r_{1}\right\rangle}$, $W_{C}^{\left\langle r_{2}\right\rangle}, W_{u}^{\left\langle r_{4}\right\rangle}, W_{F}^{\left\langle r_{5}\right\rangle}, W_{T}^{\left\langle r_{6}\right\rangle}, \ldots$, each of which may represent a scalar or more generally a vector that is created by group of indicators of the effectiveness of this.

Partial indices $W_{\mathrm{r}}, \quad r=\overline{1, R}$ efficiency, reliability (reliability), economic, social and other types of performance form a vector efficiency $\vec{W}$ index of restoration of objects of combine harvesters in the process and repair management

$\vec{W}(u)=\left(W_{1}(u), W_{2}(u), \ldots, W_{r}(u), \ldots, W_{R}(u)\right), \quad r=\overline{1, R}$, where $\mathrm{R}$ is the total number of partial indicators of the effectiveness of the recovery process.

Indicators in the evaluation of the effectiveness of the process of technical operation of the vessel, and hence the operation of the recovery system combine harvesters, as a rule, divided into the indicators of technical efficiency and economic efficiency.

Indicators of technical efficiency. In accordance with the purpose of functioning of the repair system, effectiveness of the recovery system on-Board equipment of combine harvesters we understand its ability to maintain a given level of readiness of combine harvesters to carry out tasks as directed.

Thus, the problem reduces to the selection of indicators to quantify the quality of recovery of the system and its impact on the efficiency of the process of technical operation of combine harvesters.

A property of the system of technical maintenance and repair of grain harvesters to complete the task relatively continuous maintain a given degree of readiness of combine harvesters to carry out tasks is determined by its effectiveness which includes the technical perfection of design and operational reliability of grain harvesters.

Numerous studies evaluating the effectiveness of the process of technical maintenance of combine harvesters, show that the willingness of harvesters to use is largely determined by its reliability. Moreover, the reliability depending on the purpose of the study refers to the combination of such elements as: reliability, maintainability, durability and persistence.

Since the main function of system restore is the translation of the object of repair to a healthy state, it is logical to assume that system restore affects the efficiency of the object through the characteristics of its reliability. 
On the other hand, the main requirement when selecting a performance indicator is a compliance indicator the purpose of the study the aim of this study is to improve the system of technical maintenance and repair of combine harvesters, so that as the main figure should choose one of the indicators of reliability.

All the components of reliability are assessed using quantitative parameters.

In the practice of evaluation of reliability of combine harvesters used the figures given in the table 1 .

Table 1. Main indicators of reliability of combine harvesters.

\begin{tabular}{|c|c|c|}
\hline Property & Index & Marking \\
\hline \multicolumn{3}{|c|}{ Single } \\
\hline \multirow{5}{*}{ Reliability } & Probability of failure & $P(t)$ \\
\hline & Failure rate & $\lambda(t)$ \\
\hline & $\begin{array}{l}\text { Parameter flow of } \\
\text { failures }\end{array}$ & $\omega(t)$ \\
\hline & $\begin{array}{l}\text { Average time to } \\
\text { failure }\end{array}$ & $T_{1}$ \\
\hline & $\begin{array}{l}\text { Average time to } \\
\text { failure }\end{array}$ & $T_{0}$ \\
\hline \multirow{3}{*}{ Durability } & Average resource & $T_{n}$ \\
\hline & $\begin{array}{l}\text { Service resource } \\
\text { (average service } \\
\text { resource) }\end{array}$ & $T_{e}$ \\
\hline & $\begin{array}{l}\text { Gamma-percent } \\
\text { service resource }\end{array}$ & $T_{\gamma e \%}$ \\
\hline \multirow{3}{*}{ Maintainability } & $\begin{array}{l}\text { Probability of } \\
\text { recovery }\end{array}$ & $P_{e}$ \\
\hline & Recovery rate & $\mu(t)$ \\
\hline & $\begin{array}{c}\text { Average duration of } \\
\text { recovery }\end{array}$ & $T_{6}$ \\
\hline \multirow{2}{*}{ Persistence } & $\begin{array}{l}\text { Average time } \\
\text { persistence }\end{array}$ & $T_{3}$ \\
\hline & $\begin{array}{c}\text { Gamma-percent } \\
\text { resource persistence }\end{array}$ & $T_{\gamma 3} \%$ \\
\hline \multicolumn{3}{|c|}{ Integrated } \\
\hline \multirow{3}{*}{$\begin{array}{l}\text { Reliability and } \\
\text { maintainability }\end{array}$} & Availability & $K_{2}$ \\
\hline & $\begin{array}{c}\text { Coefficient of } \\
\text { operational readiness }\end{array}$ & $K_{o 2}$ \\
\hline & $\begin{array}{l}\text { Coefficient of } \\
\text { technical use }\end{array}$ & $K_{m \varepsilon}$ \\
\hline
\end{tabular}

As can be seen from table 1 , the individual indicators of reliability characterize one of the properties of a technical object (e.g., reliability) while integrated indicators characterize several properties.

The main indicators of reliability of non-renewable combine harvesters in accordance with DSTU 2862 is the probability of failure, failure rate, mean time between combine harvesters to failure. The probability $P(t)$ of failure-free operation of combine harvesters is the probability that within a given experience of failure will not occur, that is, the object began to work at time $t=0$, to perform reliably over time $t$ :

$$
P(t)=P(\xi>t)=1-F_{\xi}(t),
$$

where: $\xi$ - random operating time of combine harvesters to failure, $F_{\xi}(t)$ - distribution function developments combine harvesters to failure.It is obvious that the distribution function of the achievements of combine harvesters to failure $F_{\xi}(t)$ the probability of failure of the object over time $t$.

In differential form the law of distribution of time to failure is called the density of distribution of time to failure $f_{\xi}(t)$ :

$$
f_{\xi}(t)=-\frac{\partial P(t)}{\partial t}
$$

Value characterizes $f_{\xi}(t) \partial t$ the probability of failure over a range $(t+\partial t)$ of developments combine harvesters, taken at random from the set of identical harvesters.

It is unknown whether this functional object to the beginning of the interval at the time $t$, was denied informed. It's not always convenient in practice $f_{\xi}(t)$, as an independent indicator finds limited application.

Often used similar definition of failure rate:

$$
\lambda(t)=\frac{f_{\xi}(t)}{P(t)} .
$$

Failure rate, generally regarded as the relative rate of reduction in the value of the reliability function $P(t)$ with increasing $t$.

Performance elements of the combine harvesters (functional systems, modules, assemblies, parts) characterized by their serviceability, that is, the condition that meets the requirements of normative-technical documentation. Any deviation from the technical requirements is considered as a fault and is defined by the term rejection.

Combine harvesters and their functional systems relate to the recovery of objects, the performance which in case of detection of failure to restore these conditions by repair or replacement of nodes or elements, that had failed. The process of their functioning is described by continuous random variables characterizing the length of time of correct operation, $T$, the duration of the recovery period $T_{\text {відн }}$, or time between failures and updates

$$
T_{\Sigma}=T+T_{\text {відн }} .
$$

In addition, we introduce a discrete random variable characterizing the number of failures $n\left(t_{i-1}, t\right)$ or recoveries $n_{B}\left(t_{i-1}, t\right)$ over a period of time $\left[t_{i-1}, t\right]$.

As features the average number of failures expected in a small period of time for recovery of objects using a parameter of stream of refusals $\omega(t)$, that for ordinary stationary flow failure is determined by the formula

$$
\omega(t)=1 / T_{0},
$$

i.e. $\omega(t)$ - expected number of failures of combine harvesters with the recovery per unit time for steady-state operation. 
Usually in the theory of reliability, as a rule, do not distinguish between intensity and parameter flow of failures, due to the fact that the stream of refusals is physically there always ordinary. Therefore, the parameter of stream of refusals is asymptotically equal to the probability of failures in the interval $\Delta t$.

One of the quantitative indicators of reliability of combine harvesters being restored is the average time between failures:

$$
T_{0}=\frac{T}{M[n(t)]},
$$

where: $M[n(t)]$ - the expected number of failures over a given period of operating time $T$.

The individual indicators of reliability have a peculiar technological character: they are necessary for use in calculations of integrated (operational) indicators of reliability of combine harvesters. These indicators are intended for subsystems (elements) of complex technical systems (CTS). For example, if CTS is convenient to characterize the availability (operational metric), each of the constituent elements must be characterized by a single performance - distribution practices and the recovery time (or their main parameters such as mathematical expectation) as they allow to calculate the reliability index of the system as a whole, taking into account features of the processes of operation and maintenance.

It should be noted that the statistical material these parameters are calculated by the operating time of combine harvesters excluding downtime for operations and $\mathrm{R}$.

To account for periods of repair and maintenance are calculated complex indicators of reliability. These include the coefficient of readiness, coefficient of operational readiness and the coefficient of technical use.

Availability factor $\mathrm{Kg}(\mathrm{t})$ is defined as the likelihood that harvesters will be in working state at any time, except the planned periods during which the use of combine harvesters for the purpose not provided.

For any distribution of achievements between failure and recovery time can prove that the stationary availability factor is equal to:

$$
K_{2}=\frac{M\left(T_{0}\right)}{M\left(T_{0}\right)+M\left(T_{b}\right)},
$$

where: $M\left(T_{0}\right)$ - average time of finding combine harvesters in good condition,

$M\left(T_{B}\right)$ - average recovery time combine harvesters.

The dependence of $K_{2}(\mathrm{t})$ on time is often called the nonstationary availability factor (function ready). To obtain the expression for non-stationary coefficient of readiness in the analytical form is quite complicated in the General case

$$
K_{2}(t)=P(t)+\int_{0}^{t} P(t-\tau) \cdot \omega_{B}(\tau) d t,
$$

where: $\omega_{B}(\tau)$ - parameter of stream restorations.

In DSTU introduce also the notion of the coefficient of operational readiness $K_{2}(t, t+\tau)$ as the probability that the object will be in working order for any period of time, except for planned periods during which the use of combine harvesters for the purpose provided, and from this point on, will work flawlessly within a given time interval $\tau$.

$$
K_{2}(t, t+\tau)=P(t+\tau)+\int_{0}^{t} P(t+\tau-x) \cdot \omega_{B}(x) d t .
$$

Along with the availability factor in the study of influence of methods and regimes of maintenance on the efficiency of the process of technical operation used $K_{m b}$ the coefficient of technical use is equal to the ratio of mathematical expectation (MO) time interval of stay of combine harvesters in a healthy state for a certain period of operation $M\left(T_{0}\right)$ to the sum of the MO residence time of combine harvesters in working condition and the total downtime in all types of maintenance and repairs is $M\left(T_{n p}\right):$

$$
K_{m b}=\frac{M\left(T_{0}\right)}{M\left(T_{0}\right)+M\left(T_{n p}\right)},
$$

where: $M\left(T_{n p}\right)$ - the sum of mathematical expectations of downtime of combine harvesters on a periodic, regular, seasonal work, when carrying out improvements, repairs, Troubleshooting and so on.

The analysis of the advantages and disadvantages of the above indicators of technical efficiency shows that as the indicator that characterizes the efficiency of organizational structures, from the point of view of providing the required level of readiness of combine harvesters to the application, it is advisable to choose a stationary coefficient of readiness $K_{2}$, characterizing the readiness of combine harvesters to be used in an arbitrary sufficiently remote period of time and defined as the value of the coefficient of readiness defined by the working conditions of combine harvesters, when the average parameter flow of failures and the average duration of the recovery remain constant. Stationary availability factor is a complex indicator of reliability that characterizes simultaneously two different object properties - reliability and maintainability.

It is clear that when using this indicator, the impact of the system recovery determines the average recovery time depends on many factors (comprehensiveness and technological cooldown system, logistics, etc.).

The next task is the selection of the indicators, giving a quantitative estimate on the price achieved or that the value of the stationary coefficient of readiness for the chosen variant of the organization of the recovery system $u, u \in U$.

Under the economic indicators of complex engineering systems understand the indicators of the expenditures for the development, manufacture and operation of products and economic efficiency of its operation.

Abroad, in the practice of the design and operation of combine harvesters found a use method of assessing the effectiveness of the concepts developed according to the indicator life-cycle costs.

Under the life cycle cost of a system refers to a specific type of integral discounted the cost of its development, production and operation. 
Under the life cycle (LC) system is the calendar time period covering the stage of research, development and testing stage of production the required number of systems and the operational stage.

The leading foreign construction firms have developed a number of methods for evaluating the lifecycle cost of the ship and engines on the basis of mathematical models, allowing to calculate the values on the electronic computing machines (computers).

So, according to foreign sources known to the analytical model of the lifecycle cost of combine harvesters and engines of combine harvesters, which were used to optimize the tactical and technical parameters of the prospective combine harvesters, as well as operational and technical characteristics of hell to them.

As a rule, the indicator of life cycle cost is used as objective function for optimization of the processes of development, production and operation of combine harvesters on the stage. It is an integrated indicator, giving the opportunity to more fully consider the costs and effects at all stages of the life cycle. Cost analysis of life cycle objects combine harvesters allows to obtain at the early stages of creating the information necessary for the evaluation of the decisions taken at various stages of the life cycle.

Because the harvesters not a manufacturing sector and does not give a positive economic effect resulting from its operation, to evaluate the economic efficiency of functioning of system operation of grain harvesters it is advisable to use only those indicators that reflect the magnitude of different cost elements (material, energy $\mathrm{E}$ and labour Tr, F financial, etc.) presented in any form (absolute, relative, specific, reduced), to achieve a certain result.

In the proposed to evaluate the economic efficiency of the process of technical operation of combine harvesters in the parameters of the cost and complexity of IT and $\mathrm{R}$.

Labour intensity $T_{r_{\text {num }}}^{\text {TO }}$ (the ratio of the complexity that is mathematical expectation of the total labor costs for maintenance of combine harvesters for a certain period of operation to mathematical expectation of the developments of combine harvesters during this period:

$$
T_{r}^{\text {TO }}(T)=\frac{M\left[\sum_{i=1}^{N} T_{r T o i}\right]}{M\left[\sum_{i=1}^{I} t_{0 i}\right]},
$$

where $T_{r_{T O i}}$ the effort required to conduct the i-th,

$N$ - number of works for the period of operation, which is considered

$t_{0 i}$ - life object as a part of combine harvesters in the i-th cycle of operation.

Taking into account the above notation, we get:

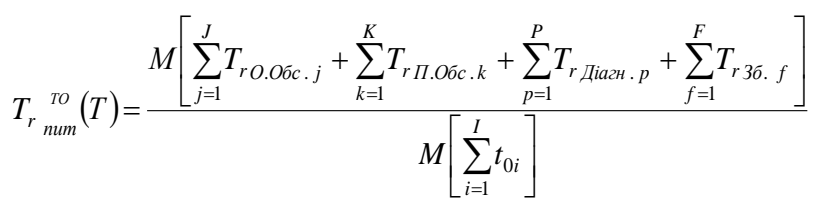

where $T_{\text {rO.Обс.j }}$ - period of operation of combine harvesters is considered:

$T_{r \text { П.Обс.k}}$ - labor for $k$ operational services,

$T_{r \text { Діагн.p }}-$ work on the periodic maintenance, effort required to perform the robot, the diagnostics of combine harvesters,

$T_{r 36 . f}-$ work on the execution of works on the first save.

The specific complexity of the repairs $T_{r}^{\text {Рum. }}$ (the ratio of the complexity of the repairs) is the mathematical expectation of the total labor costs for carrying out all types of repairs of objects of combine harvesters for a certain period of operation to the mathematical expectation of the operating time of the object during the same period:

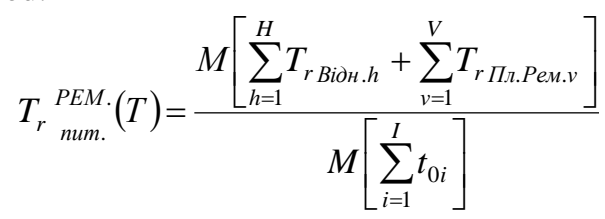

where: $T_{r \text { Вiдн.h }}-$ the effort at elimination on the h-th failure or refusal,

$T_{r_{\text {Пл.Рем.v }}}$ - work $v$-th planned maintenance.

It is obvious that the figures $T_{r_{n u m}}^{T O}$ and $T_{r_{n u m}}^{P e n}$ expressed by the formula value that will correspond to the unit cost of maintenance $C_{\text {num }}^{T O}(T)$ and the unit cost of repair of combine harvesters $C_{\text {num }}^{P e s}(T)$, respectively.

Integrated assessment process the technical operation of combine harvesters from the point of view of economic efficiency, regardless of the adopted strategy and $C_{\text {num }}^{\text {ПTE }}$ combine harvesters, use the index of unit costs of process of technical exploitation as the ratio of expected costs of the process of technical maintenance of combine harvesters during the period of operation expressed in value or complexity, the mathematical expectation of the operating time of the object during the same period, and that taking into account the accepted notation takes the form

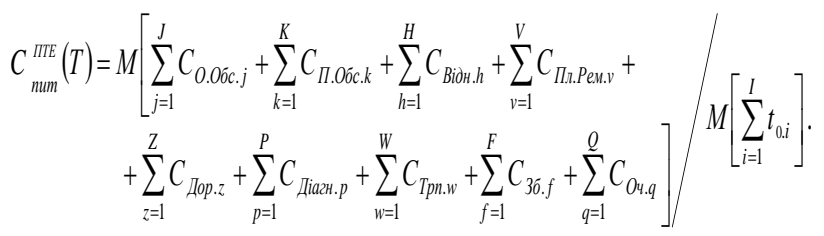

where $C_{\text {O.обс.j }}-$ cost of $\mathrm{j}$ operational services,

$C_{\text {I. Обс.k }}$ - the cost of k-th periodic maintenance,

$C_{\text {Відн.h }}$ - the cost of restoration of h-th failure or refusal, 
$C_{\text {Пл.Рем.v }}-$ the cost of carrying out the n-th planned maintenance

$C_{\text {Діагн.p }}-$ the cost of performing work at the p-th object diagnostics of combine harvesters,

$C_{\text {Дор.z }}-$ the cost of performing j-th job,

$C_{\text {Tpn.w }}$ - the cost w-transportation (delivery) of combine harvesters,

$C_{36 . f}$ - the cost of the f-saving (idle period in good condition) objects combine harvesters,

$C_{O \psi . q}-$ costs associated with the expectation of combine harvesters of various types and repiar.

As can be seen from the expression rate in contrast $C_{\text {num. }}^{\text {ITE }}, C_{\text {num }}^{T O}$ and $C_{\text {num. }}^{P e s}$, allows to take into account one indicator of the redistribution of the costs of the process of technical operation (PTO) combine harvesters between operational, periodic types and scheduled, unscheduled repairs with the economic assessment of different strategies and repiar.

But considering the purpose of the study, when determining the cost of recovery of combine harvesters during operation due to the fact that the process of recovery combine harvesters does not affect the regimes and the adoption of the strategy and repiar, cost accounting at operational, periodic, seasonal works, planned repairs and improvements does not make sense. Additionally, if you select one option or the other organizations of the recovery process, more important is the definition of a direct cost recovery system for reaching a specified level of serviceability combine harvesters.

Recovery system for combine harvesters as an integral part of the system of technical maintenance and repair has a significant impact on quantitative and qualitative characteristics of the exchange Fund combine harvesters. Therefore, when determining the cost of recovery of grain harvesters, it is necessary to consider the cost of the system to ensure (supply) for the creation, storage, transportation and replenishment of the exchange fund combine harvesters.

Thus the costs for repairing the combine harvester during operation is proposed to determine how the total cost of the recovery system and supply system according to the expression

$$
M\left[C_{6 \Sigma}(T)\right]=M\left[C_{6}(T)\right]+M\left[C_{3 \sigma}(T)\right],
$$

where: $M\left[C_{B \Sigma}(T)\right]-$ the average total recovery cost of combine harvesters during the period under review,

$M\left[C_{B}(T)\right]$ - average cost for the restoration of combine harvesters during the period under review,

$M\left[C_{3 \sigma}(T)\right]-$ the average cost of the assurance system in the reporting period.

The cost recovery of complex technical systems, consisting of a large number of blocks, modules, circuit boards or other structurally-replaceable units (the COA), without considering the cost of Troubleshooting the failure of the block in the operating organization, it is advisable to assess by using the expression:

$$
M\left[C_{B}(T)\right]=\sum_{i=1}^{k} C_{\sigma_{i}} \cdot\left(1-Q_{B_{i}}\right) \cdot M\left[n_{i}(T)\right],
$$

where: $M\left[C_{b}(T)\right]$ - the mathematical expectation of costs for recovery of combine harvesters during the period under review,

$C_{\sigma_{i}}$ - the purchase price of the object of combine harvesters (unit, unit, unit) of the i-th type,

$Q_{B_{i}}$ - complete reconstruction of the i-th unit in the operating organization,

$M\left[n_{i}(T)\right]$ - the average number of substitutions of the $i$-th block (COA) system for the period of operation of

$k-$ the number of types, the user will be restored.

Costs of providing system using the define method, as described by the expression:

$$
\begin{aligned}
M\left[C_{3 \sigma}(T)\right]= & \frac{1}{t_{3}}\left\{T \cdot C_{34} \cdot k+M\left[\left(C_{m p n}\right)\right]+C_{3} \cdot\left\{k \cdot T \cdot e^{-N \cdot \lambda \cdot T}+\right.\right. \\
& \left.\left.+\sum_{i=1}^{k} \frac{N \cdot \lambda \cdot T}{i !} \cdot e^{-N \cdot \lambda \cdot T} \cdot\left\{(k-i) \cdot T+\sum_{j=1}^{i} M\left[\tau_{j}\right]\right\}\right\}\right\}
\end{aligned}
$$

where: $M\left[C_{36}(T)\right]$ - the average cost of the assurance system during the period under review,

$C_{34}$ - the purchase price, $\mathrm{COA}$,

$M\left[\left(C_{m p n}\right)\right]$ - the average cost of the system to ensure transportation of spare parts for the period that is investigated,

$C_{3}$ - notional value saves one $\mathrm{CC}$ for one hour,

$N$ - the number of objects of a particular type of operation,

$\lambda$ - the failure rate of an object combines harvesters,

$T$ - the period of time that is considered,

$t_{3}$ - interval AF procurement,

$M\left[\tau_{j}\right\rfloor$ - the expected time to the occurrence of the first failure in a finite time interval $T$,

$k$ - the scope of supply (procurement) during the study time, which is defined as

$$
k=\left(M\left[n_{i}(T)\right]-l\right),
$$

where: $l$ - point of order.

Based on the analysis of existing indicators of the effectiveness of complex technical systems and the objectives of the study proposes to assess the influence of the recovery system of combine harvesters on efficiency of their maintenance and repair using the following indicators:

$K_{2}$ - stationary coefficient of readiness of combine harvesters,

$$
\left.M \mid C_{B \Sigma}(T)\right]- \text { the average total cost of recovery }
$$
of combine harvesters during the period under review,

$M\left[n_{B}(t)\right]$ - the average number of substitutions (recoveries) combine harvesters for a certain period of operation.

Thus, the selected basic indicators of efficiency of functioning of systems of combine harvesters, which fully 
reflect its impact on the efficiency of the process and $\mathrm{R}$ combine harvesters that operated.

Existing approaches to the assessment of technical and economic efficiency of combine harvesters differ in the degree of the given set of objects, which are investigated, and the period of their functioning.

As practice shows techno-economic assessment of complex technical objects define four approaches in which last seen:

1) as a single object,

2) the totality of the Park of the same objects,

3 ) in a certain operating organization,

4) in the aggregate of organizations operating the same type of objects.

The first and third approaches generally relate to the formulation in statics, i.e. relative to some fixed point in time, the second and fourth approaches involve dynamic methods of solving the problem by evaluating the technical and economic efficiency of technical objects.

The choice of a particular approach is determined by the purpose of the task, which is solved.

In addition, analysis of these approaches shows that the choice of a particular one depends essentially on the completeness and volume of the original information of the monitored process of technical operation of technical objects at the time of the study.

Detailed and complete source of information about the process under study, allows to receive more accurate and complete characterization of the operation of the facility and make the most informed decisions for management of the technical condition of the exploited.

However, in practice, have only a limited amount of input data, usually determined by the stage of the life cycle of the object on which the research is being conducted. For example, during the development phase of a technical object provides the least amount of information regarding actual operational performance of the new object, while at the stage of mass exploitation on the basis of the results of the statistical evaluation of the functioning of the park of the same objects there is the most complete and reliable information.

In this regard, it is advisable to use different approaches towards techno-economic assessment of the process of technical maintenance of combine harvesters.

From the analysis of literature, devoted to technicaleconomic estimation of objects of the combine harvesters, the methods currently used to predict the performance of their efficacy at various stages of the life cycle, are divided into three groups.

1. Methods based on the collection of statistical information and evaluation of actual values of indicators of technical and economic efficiency of existing models of technical objects, as well as methods of extrapolation and interpolation based on the use of the principle of analogy to objects that are created. At the core of these methods is the study of the relationship of the key operational and technical characteristics of analogues (prototypes) with indicators of technical and economic efficiency, extrapolation and interpolation of these ties on the parameters of the objects that are investigated.

2. Structural-logical methods and decision trees (methods of examination), are to determine the trends in the indicators of technical and economic efficiency on the basis of expert assessments. This uses the questionnaire survey, the weighted estimates, metric methods, the method of paired evaluations, etc.

3. Methods of mathematical modeling allow to investigate the dynamics of performance indicators in key operational and technical characteristics of combine harvesters, modes and repair, maintenance strategy.

Each of these methods has its advantages and disadvantages, which determine their degree of applicability to predict the performance indicators for different stages of the life cycle combine harvesters.

So to predict the technical and economic indicators at the stages of development and production is most commonly used in domestic and in foreign practice, methods of analogies and expert estimations, while for forecasting the costs of maintenance and repair uses different methods of modeling.

The main disadvantage of the methods of the first group is the necessity of practical implementation of methods and modes, and repair to obtain the statistical data that is associated with the risk of significant material losses.

Structural-logical methods are quite simple to apply, but require a large number of experts to develop appropriate schemes of decision-making that is not always possible.

In addition, these methods have the following disadvantages: subjective views of experts, the inability to assess the adequacy of the decisions taken, the solution of the problem only on a qualitative level, without a quantitative assessment of performance indicators.

Basic research tool of efficiency of processes of technical maintenance in conditions of rapid development of computer technology are the methods of the third group. Distinguish between analytical, simulation and combined mathematical models. Simulation models of operating processes based on simulation, usually with the help of computers, accumulation products developments, operations and repair, write-off, the formation of reserves and the like. Simulation models are largely adequate to the processes that are investigated, but require a much larger volume of information than analytical, the time of preparation of source data and calculation.

Methods of simulation allow relatively easy to quantify the efficiency of the process of maintenance of technical system construction of complex models, and successfully complement analytical methods of solution in the case of the bulkiness of the latter.

But simulation has the following significant drawbacks: the impossibility of obtaining optimal solutions in a compact mathematical form, low visibility, large amounts of computation.

Most fully able to examine the efficiency of the process of operation of complex technical systems (CTS) using analytical models.

Analytical models (in discrete or continuous form) of processes of functioning of CTS that uses the theory of recovery, the theory of random processes, sequential analysis, theory of inventory management, mathematical programming can solve a wide range of tasks that are limited by the difficulties of computational character.

The development of computational techniques has allowed to generate and implement on a computer more 
complex analytical models of operational processes of CTS, represent a system of integro-differential equations which are reduced to the recurrent differential procedures and are solved by numerical methods.

In the analytical models of the process of functioning of object of the research is presented in the form of certain functional relations or logical conditions.

The most complete study can be carried out while obtaining the explicit dependencies linking activities performance indicators with the parameters that characterize a process of technical operations, and the initial conditions of the study.

The analysis suggests that the most rational approach to evaluation and forecasting of technical and economic efficiency of the process of technical maintenance of combine harvesters in the assessment of the effect of the introduction of hardware-software means of control and diagnostics of its technical condition, the effects of different operational parameters and modes, and repair, alternative recovery strategies marine systems is mathematical modeling of the process that is investigated.

\section{Conclusions}

1. To assess the effectiveness of the process of technical maintenance of combine harvesters have developed and applied a wide range of indicators. Therefore, to implement a comprehensive assessment of the impact of the recovery process dismantled due to the failure of equipment combine harvesters on technical and economic efficiency of the process of technical operation of grain harvesters it is necessary to use a vector performance indicator that includes a number of private utilization, reliability and economic efficiency with the isolation of the group overall, the most important indicators.

2. Comparative analysis of different methods and approaches showed that the task of estimation and forecasting of technical and economic efficiency of the process of technical operation of modern combine harvesters, taking into account various operational factors, the strategy they then repair must be solved with the use of the concept of mathematical modeling.

\section{References}

1. Antonov A. I. (2011). Transient process in a twodimensional extremal system in the presence of forbidden regions and a random search method. Statistical optimization problems. Riga: Zintane. 69-81.

2. Medvedev G. A., Ryzhakov A. P. (2011). On the application of random search algorithms in automatic optimization systems. Statistical optimization problems. Riga. Zintane. 81-92.

3. Rastrigin L. A., Ripa K. K. (2013). Automatic theory of random search. Riga. Zintane. 342.

4. Taev I. S., Egorov E. G., Gorshkov Yu. E., Popova E. P. (2011). Optimization of parameters of the electric apparatus arc-extinguishing chamber. Moscow. Low voltage devices. 1(92). 24-32.
5. Petrov A. A. (2017). Numerical methods of conditional optimization. Moscow. Myr. 290.

6. Box M. J. (2015). A new method of constrained optimization and a compare son with other methods. Computer. 8. 42-52.

7. Burkhard G. (2014). Uber das Lichtbogenverha1ten in Loschkammern und derem Bemessung. E1ektrie. E05. 96-105.

8. Hooke R., Jeeves T. (2011). Direct seach solution of numerical and ststist1cal problems. JACM. 8. 212-229.

9. Klingman W. R., Himmelblau D. M. (2014). Nonlinear programming with the aid of a multiple gradient summation technique. JACM. 11. 400-415.

10. Luws R., Jaakola T. (2013). Optimization by direct search and systematic reduction of the size of seach region. Ch.E. Journal. 19. 760-766.

11. Rosenbrock H. H. (2020). An automatic method for finding the greatest or least value of a function. Computer. 3. 175-184.

12. Rumelhart D. E. (2016). Learning representations of back-propagation errors. Nature. 323. 533-536.

13. Rekleytis G. (2016). Optimization in technology. Moscow. Myr. 220.

14. Goldberg D. E. (2019). Genetic Algorithms in Search, Optimization, and Machine Learning. AddisonWesley, 308.

15. Kolkov D. A. (2006). Analysis of interval methods of searching for a global extremum. Fundamental research. 2. 22-23.

16. Rogovskii I. L., Titova L. L., Trokhaniak V. I., RosamahaYu.O., BlesnyukO.V., Ohiienko M.M. Ohiienko A. V. (2019). Engineering management of twophase coulter systems of seeding machines for implementing precision farming technologies. INMATEH. Agricultural Engineering. 2019. 58(2). 137146. doi: 10.35633/INMATEH-58-15.

17. Romaniuk W., Polishchuk V., Marczuk A., Titova L., Rogovskii I., Borek K. (2018). Impact of sediment formed in biogas production on productivity of crops and ecologic character of production of onion for chives. Agricultural Engineering (wir.ptir.org). Krakow. Poland. 22(1). 105-125. https://doi.org/10.1515/agriceng2018-0010.

18. Rogovskii I., Titova L., Trokhaniak V., Trokhaniak O., Stepanenko S. (2019). Experimental study in a pneumatic microbiocature separator with apparatus camera. Bulletin of the Transilvania University of Brasov, Series II: Forestry, Wood Industry, Agricultural Food Engineering. 12(1). 117-128.

19. Titova L. L., Rogovsky I. L. (2014). Methodical provisions of the need for mobile means of maintenance of forest MEZ. Scientific Herald of National University of Life and Environmental Science of Ukraine. Series: Technique and energy of APK. Kyiv. 196(3). 146-152.

20. Titova L. L., Rogovsky I. L. (2014). Methods of maintenance of forest machines. Bulletin of the Petro Vasylenko Kharkiv National Technical University of Agriculture. Kharkiv. 155. 132-137.

21. Titova L. L., Rogovskii I. L. (2015). Substantiation of technical measures to maintain the efficiency of machines for forestry work. Bulletin of the 
Petro Vasylenko Kharkiv National Technical University of Agriculture. Kharkiv. 160. 189-195.

22. Titova L. L., Rogovsky I. L. (2015). Analysis of periodicity of maintenance of machines for forestry works. Scientific Herald of National University of Life and Environmental Science of Ukraine. Series: Technique and energy of APK. Kyiv. 2015. 212(1). 322-328.

23. Rogovskii I., Titova L., Novitskii A., Rebenko V. (2019). Research of vibroacoustic diagnostics of fuel system of engines of combine harvesters. Engineering for Rural Development. 18. 291-298.

\section{Список літератури}

1. Антонов A. И. Переходный процесс в двумерной экстремальной системе при наличии запрещенных областей и случайном методе поиска. Задачи статистической оптимизации. Рига: Зинтане, 2011. C. 69-81.

2. Медведев Г. А., Рыжаков А. П. О применении алгоритмов случайного поиска в системах автоматической оптимизации. Задачи статистической оптимизации. Рига: Зинтане, 2011. С. 81-92.

3. Растригин Л. A., Рипа K. К. Автоматная теория случайного поиска. Рига: Зинтане, 2013. 342 с.

4. Таев И. С., Егоров Е. Г., Горшков Ю. Е., Попова Е.П. Оптимизация параметров дугогасительной камеры электрического аппарата. Москва. Аппараты низкого напряжения. 2011. Вып. 1(92). С. 24-32.

5. Петров A. A. Численные методы условной оптимизации. Москва. Мир. 2017. 290 с.

6. Box M. J. A new method of constrained optimization and a compare son with other methods. Computer. 2015. №8. P. 42-52.

7. Burkhard $G$. Uber das Lichtbogenverha1ten in Loschkammern und derem Bemessung. E1ektrie. 2014. Vol. E05. P. 96-105.

8. Hooke R., Jeeves $T$. Direct seach solution of numerical and ststist1cal problems. JACM. 2011. Vol. 8. P. 212-229.

9. Klingman W. R., Himmelblau D. M. Nonlinear programming with the aid of a multiple gradient summation technique. JACM. 2014. Vol. 11. P. 400-415.

10. Luws R., Jaakola T. Optimization by direct search and systematic reduction of the size of seach region. Ch.E. Journal. 2013. Vol. 19. P. 760-766.

11. Rosenbrock H. H. An automatic method for finding the greatest or least value of a function. Computer. 2020. Vol. 3. P. 175-184.

12. Rumelhart D. E. Learning representations of back-propagation errors. Nature. 2016. Vol. 323. P. 533536.

13. Реклейтис Г. Оптимизация в технике. Москва. Мир. 2016. 220 с

14. Goldberg D. E. Genetic Algorithms in Search, Optimization, and Machine Learning. Addison-Wesley, 2019. 308 p.

15. Колков Д. А. Анализ интервальных методов поиска глобального экстремума. Фундаментальные исследования. 2006. Вып. 2. С. 22-23.
16. Rogovskii I. L., Titova L. L., Trokhaniak V. I., RosamahaYu.O., Blesnyuk O. V., Ohiienko M. M. Ohiienko A. V. Engineering management of two-phase coulter systems of seeding machines for implementing precision farming technologies. INMATEH. Agricultural Engineering. 2019. Bucharest. Vol. 58. No 2. P. 137-146. doi: 10.35633/INMATEH-58-15.

17. Romaniuk W., Polishchuk V., Marczuk A., Titova L., Rogovskii I., Borek K. Impact of sediment formed in biogas production on productivity of crops and ecologic character of production of onion for chives. Agricultural Engineering (wir.ptir.org). Krakow. Poland. 2018. Vol. 22. №1. P. 105-125. https://doi.org/10.1515/ agriceng-2018-0010.

18. Rogovskii I.,

Titova L., Trokhaniak V., Trokhaniak O., Stepanenko S. Experimental study in a pneumatic microbiocature separator with apparatus camera. Bulletin of the Transilvania University of Brasov, Series II: Forestry, Wood Industry, Agricultural Food Engineering, 2019. Vol. 12 (1). P. 117-128.

19. Тітова Л. Л., Р Роговський І. Л. Методичні положення потреби в мобільних засобах техобслуговування лісових МЕ3. Науковий вісник Національного університету біоресурсів i природокористування України. Серія: техніка та енергетика АПК. Київ. 2014. Вип. 196, ч. 3. С. 146152.

20. Тітова Л. Л., технічного обслуговування лісових машин. Вісник Харківського національного технічного університету сільського господарства імені Петра Василенка. Харків. 2014. Вип. 155. С. 132-137.

21. Тітова Л. Л., Роговський І. Л. Обгрунтування технічних заходів підтримання працездатності машин для лісотехнічних робіт. Вісник Харківського національного технічного університету сільського господарства імені Петра Василенка. Харків. 2015. Вип. 160. С. 189-195.

22. Тітова Л. Л., Р Роговський І. Л. Аналіз періодичності техобслуговування машин для лісотехнічних робіт. Науковий вісник Національного університету біоресурсів і природокористування України. Серія: техніка та енергетика АПК. Київ. 2015. Вип. 212, ч. 1. С. 322-328.

23. Rogovskii I., Titova L., Novitskii A., Rebenko V. Research of vibroacoustic diagnostics of fuel system of engines of combine harvesters. Engineering for Rural Development. 2019. Vol. 18. P. 291-298.

\section{АНАЛІЗ ЕФЕКТИВНОСТІ ПРОЦЕСУ ЕКСПЛУАТАЦІЙНОЇ І ТЕХНОЛОГІЧНОЇ НАДІЙНОСТІ СІЛЬСЬКОГОСПОДАРСЬКИХ МАШИН P. Ф. Овчар}

Анотація. Проведений аналіз свідчить про те, що для вирішення протиріччя між необхідністю забезпечення необхідного рівня працездатності комбайнів i можливостями існуючої системи i управлінням ремонтом технічного стану комбайнів на сучасному етапі необхідно вдосконалювати підсистему відновлення комбайнів 3 урахуванням вимог готовності до виконання завдань за 
призначенням та фінансових можливостей для іiі обслуговування .

Аналіз наукової літератури показав, що на сьогоднішній день невирішеними проблемами пошуку і впровадження ефективних методів ремонту зернозбиральних комбайнів $\epsilon$ : розробка математичних моделей процесу і ремонту, що дозволяють проводити порівняльну оцінку техніко-економічної ефективності різних режимів, об'єктів ремонту комбайнів, альтернативних стратегій їх ремонту, 3 метою підвищення якості контролю технічного стану машини в умовах обмеженого фінансування.

Розгляд процесу технічного обслуговування зернозбиральних комбайнів як сукупності етапів i об'єктів ремонту комбайнів дозволяє виявити можливі напрямки вдосконалення системи відновлення. Проведений аналіз дозволив визначити чотири основні варіанти його організації і якісно оцінити достоїнства і недоліки кожного з цих варіантів.

Зниження експлуатаційних витрат при експлуатації комбайнів, поряд 3 іншими заходами організаційно-технічного характеру, вимагає більшої автоматизації контролю технічного стану. Автоматизація контролю технічного стану комбайнів розроблена за наступними напрямками: вбудовані системи контролю, бортові автоматизовані системи контролю, спеціалізовані системи контролю та універсальні системи контролю демонтується обладнання. Велика частка помилкових відмов обладнання, порушення виробничих відносин в ремонтній мережі бортового обладнання, дефіцит ремонтного фонду вимагає впровадження i експлуатації.

Найбільш повно здатний досліджувати ефективність процесу роботи складних технічних систем за допомогою аналітичних моделей.

Існуючі підходи до оцінки системи рекуперації можна класифікувати також по використовуваних показниками ефективності: кількості конструктивних змінних одиниць, замінних (відновлюваних) за заданий період експлуатації об'єкта управління, ремонт вартість складових елементів функціональної системи за конкретний період при різній глибині контролю і повноти відновлення, час простою об'єкта контролю протягом певного періоду, на комплексну надійність, наприклад, коефіцієнт готовності, коефіцієнт технічне використання.

Ключові слова: аналіз, ефективність, процес, робота, технологія, надійність, комбайн.

АНАЛИЗ ЭФФЕКТИВНОСТИ ПРОЦЕССА ЭКСПЛУАТАЦИОННОЙ И ТЕХНОЛОГИЧЕСКОЙ НАДЕЖНОСТИ СЕЛЬСКОХОЗЯЙСТВЕННЫХ МАШИН

\section{Р. Ф. Овчар}

Аннотация. Проведенный анализ свидетельствует о том, что для разрешения противоречия между необходимостью обеспечения необходимого уровня работоспособности комбайнов и возможностями существующей системы и управлением ремонтом технического состояния комбайнов на современном этапе необходимо совершенствовать подсистему восстановления комбайнов с учетом требований готовности к выполнению заданий по назначению и финансовых возможностей для ее обслуживания.

Анализ научной литературы показал, что на сегодняшний день нерешенными проблемами поиска и внедрения эффективных методов ремонта зерноуборочных комбайнов являются: разработка математических моделей процесса и ремонта, позволяющих проводить сравнительную оценку технико-экономической эффективности различных режимов, объектов ремонта комбайнов, альтернативных стратегий их ремонта, с целью повышения качества контроля технического состояния машины в условиях ограниченного финансирования.

Рассмотрение процесса технического обслуживания зерноуборочных комбайнов как совокупности этапов и объектов ремонта комбайнов позволяет выявить возможные направления совершенствования системы восстановления. Проведенный анализ позволил определить четыре основных варианта его организации и качественно оценить достоинства и недостатки каждого из этих вариантов.

Снижение эксплуатационных расходов при эксплуатации комбайнов, наряду с другими мероприятияи организационно-технического характера, требует большей автоматизации контроля технического состояния. Автоматизация контроля технического состояния комбайнов разработана по следующим направлениям: встроенные системы контроля, бортовые автоматизированные системы контроля, специализированные системы контроля и универсальные системы контроля демонтируемого оборудования. Большая доля ложных отказов оборудования, нарушение производственных отношений в ремонтной сети бортового оборудования, дефицит ремонтного фонда требует внедрения и эксплуатации.

Наиболее полно способен исследовать эффективность процесса работы сложных технических систем с помощью аналитических моделей.

Существующие подходы к оценке системы рекуперации можно классифицировать также по используемым показателям эффективности: количеству конструктивных переменных единиц, заменяемых (восстанавливаемых) за заданный период эксплуатации объекта управления, ремонт стоимость составных элементов функциональной системы за конкретный период при разной глубине контроля и полноты восстановления, время простоя объекта контроля в течение определенного периода, на комплексную надежность, например, коэффициент готовности, коэффициент техническое использование.

Ключевые слова: анализ, эффективность, процесс, работа, технология, надежность, комбайн.

Р. Ф. Овчар ORCID 0000-0002-4683-3951. 